\title{
Risks to offspring of consanguineous marriage: we need straight, not crooked thinking
}

\author{
${ }^{1} \mathrm{~N}$ Qureshi, ${ }^{2} \mathrm{~S}$ Raeburn \\ ${ }^{1}$ Clinical Reader in Primary Care, University of Nottingham, UK; ${ }^{2}$ Professor Emeritus of Clinical Genetics, University of Nottingham, UK
}

KEYWORDS Consanguinity, autosomal recessive, sibship, sibling, population risk, gene frequency, carrier frequency

DECLARATION OF INTERESTS Dr Qureshi has no conflict of interests to declare. Professor Raeburn is editor of the Journal of the Royal College of Physicians of Edinburgh.

How would Robert Thouless' have responded to the recurrent debates in the UK media about the pros and cons of cousin marriage? ${ }^{2-5}$ He would surely have examined the key facts (Table I), as well as exposing any dishonest tricks of an argument; he would also have pointed out that it is wise to avoid language which alienates some participants. A senior UK scientist recently spoke about first cousin marriages ${ }^{2}$, and referred to 'inbreeding', a term which has a specific scientific meaning. Physicians wishing to engage positively with patients who are first cousins should avoid the term.

The data which led to criticism of the practice of cousin marriage in the media were collected in the Bradford area and earlier in Birmingham. ${ }^{9-12}$ In Bradford, the rate of cousin marriage in British citizens of Pakistani origin is around $75 \%$ and this community has a higher rate of congenital abnormalities, compared with the wider UK population. ${ }^{12}$ The lay press focused on these two facts, suggesting that cousin marriage causes congenital anomalies. Few articles mentioned that the families involved came from a country where birth abnormalities are more common (in Pakistan, the infant mortality rate was 57.4 per I,000 births last year, compared with the UK average of less than 5 per $1,000^{13}$ ).

Some of the greater neonatal morbidity and mortality is explained by the high incidence in Pakistan (around I person in 400) of the autosomal recessive (AR) disorder, beta-thalassaemia or by non-genetic causes (such as less access to obstetric care). But might these communities have higher rates of mutation? The danger of arguing that the problems will resolve if all communities cease to marry first cousins is that if gene mutations in the population (including AR genes) occur at a higher rate, then other marriages within that community will be at increased risk, as for the haemoglobinopathies. Eye-catching headlines may stigmatise cousin marriage or even reduce consanguinity, but this consequence alone may not significantly reduce the burden of early inherited disorders.
Correspondence to N Qureshi, Clinical Reader in Primary Care, Queen's Medical Centre, University of Nottingham, NG7 2UH, UK

tel. +44 (0) II 8466917

e-mail nadeem.qureshi@nottingham.ac.uk
TABLE I Key facts about first cousin marriages

I. Many societies prefer cousin marriages. ${ }^{6}$

2. If there is an autosomal recessive disorder in a sibship:

a) the chance of unaffected siblings being carriers is two in three; and

b) the chance of first cousins of an affected person being carriers is one in four;

c) therefore, the chance of the offspring of such a cousin marriage having the same autosomal recessive condition is I in $24(2 / 3 \times 1 / 4 \times 1 / 4)^{7.8}$

3. If the family history does not show people already affected by autosomal recessive disease in the first, second and third-degree relatives:

a) disease risk comparisons depend on knowledge of the population carrier risk;

b) the additional risk because of a first cousin marriage is usually slight;

c) but, since some recessive genes are common in certain ethnic communities, the decision to avoid marrying a first cousin may only minimally reduce risks to the children. ${ }^{6}$

This editorial is to guide physicians who wish to handle questions about genetic risks associated with consanguinity. If doctors establish the medical facts of each situation and apply genetic principles, mindful of socio-cultural factors, they will facilitate decision-making by their patients and improve insights within the community.

Our backgrounds differ but there are many issues on which we have total agreement; firstly, that to criticise families who choose cousin marriages may make them feel guilty of causing any illnesses but neither alters behaviour nor helps in tackling disease; secondly, that accepting a couple's marriage decision and providing them with accurate individualised information supports informed and appropriate decision-making. These themes are relevant in the clinic and in media discussions.

The two main scenarios for discussion about consanguineous marriage are very different: 
If a couple already have a child or children affected by an $A R$ condition

When such parents are first cousins and attend hospital for relevant treatment, they often report that doctors fixate more on the marital pattern than on disease management. But consanguinity has not caused the disorder: AR disorders are caused by homozygosity for abnormal recessive gene mutations. Cousin marriage is a factor increasing risk, not the primary cause.

\section{Couples who are first cousins ask advice about genetic risks before pregnancy}

What should the physician say? The following sequence paves the way towards reliable risk estimations:

- The views and questions of the consulting couple should be gathered first.

- A detailed family history is taken ${ }^{14,15}$, including first, second and third-degree relatives on both sides.

- If the family history uncovers a genetic disorder, details are needed and the relationship of the proband(s) to each partner must be clarified. ${ }^{14}$

- The couple's specific questions are answered as well as giving relevant risk information.

Timely help from a genetic centre is always useful, but all doctors should be able to complete and validate the family tree and give initial risk estimates. ${ }^{7,815}$ Some of the more straightforward risks should be assessed by the primary care team. ${ }^{14}$

Families who understand the reasons for an increased risk will have follow-up questions such as 'can you test others in my family for the carrier state if they wish?' or, 'can you estimate the exact risk if I marry this cousin?. If approached non-directively and with respect for their family values and choices, most couples understand the essential facts and make choices to reduce genetic risks. Unless prenatal treatment is feasible, they may not wish prenatal diagnosis, but they may consider future preimplantation genetic diagnosis if available.

What about molecular methods and the new genetics? Will they not clarify the risks immediately and simplify the clinician's work? We cannot stress enough that in the absence of a correct clinical diagnosis and without an accurate family history, molecular techniques are uninterpretable - a waste of time and money. Molecular tests may exclude risks of one specific condition, but this is irrelevant if the disease is due to a different gene.

Our take-home message is clear, but should encourage careful clinicians. Preparation of the family tree and elucidation of the social history are primary tools of clinical practice, and should be completed before launching molecular investigations. Detailed examination and diagnostic testing of affected family members, using the most relevant laboratory and imaging tests will then lead to the best genetic risk assessment. Some couples may learn that their risk is no higher than that of the population from which they come.

Such approaches will lead to more apposite research questions such as why do some populations, globally as well as in the UK, have increased rates of AR genes. We know that beta-thalassaemia carriers were selected in earlier generations because of the protection they enjoyed from malaria. What other selective factors were there (including consanguineous marriage) that may have resulted in high risk communities? We believe it is wrong to ask for a unilateral cultural change (e.g. by British citizens descended from communities originating in Mirpur in Pakistan) unless there is also a change by media and the medical profession towards the 'straight thinking' which should identify all causes and which avoids selective or emotive statements.

\section{REFERENCES}

I Thouless RH. Straight and crooked thinking. London: Pan Books; 1930.

2 Kelly T. Bradford is very inbred: Muslim outrage as a professor warns first-cousin marriages increase risk of birth defects. The Daily Mail 20I I May 30. Available at: http://www.dailymail.co.uk/ news/article-I3922 I 7/Muslim-outrage-professor-Steve-Joneswarns-inbreeding-risks.html

3 Bittles A. Here we go again: misinformation and confusion on consanguineous marriage continues. BioNews 2011 June 6 . Available at: http://www.bionews.org.uk/page 95655.asp

4 Gibb F. Rise in marriages between cousins is putting children's health at risk. The Times 20I I March 20. Available at: http://www. timesonline.co.uk/tol/news/uk/health/article7069255.ece

5 Pembrey M. Dialogue around cousin marriage is a positive step, but it must be based on fact not fiction. BioNews. Available at: http://www.bionews.org.uk/page_2567.asp\#BMS_RESULT

6 Bittles $\mathrm{AH}$, Black ML. Consanguinity, human evolution, and complex diseases. Proc Nat Acad Sci 2010; 107:1779-86. doi 10.1073/pnas.0906079106

7 Autosomal recessive inheritance. In: Young ID. Introduction to risk calculation in genetic counselling. Oxford: Oxford University Press; 2007.

8 Tobias ES, Connor M, Ferguson-Smith M. Calculation of the coefficients of relationship and inbreeding. In: Essential medical genetics. Oxford:Wiley-Blackwell; 1997.

9 Proctor S, Smith I. Factors associated with birth outcome in Bradford Pakistanis. In: Clarke A, Parsons E. Culture, kinship and genes: towards cross-cultural genetics. Basingstoke: Macmillan Press; 1997.

10 Bundey S, Alam H, Kaur A et al. Race, consanguinity and social features in Birmingham babies: a basis for prospective study. J Epidemiol Community Health 1990; 44:130-35.

II Bundey S,Alam H, Kaur A et al.Why do UK-born Pakistani babies have high perinatal and neonatal mortality rates? Paediatr Perinat Epidemiol 1991; 5:101-14.

12 Bundey S, Alam H.A five-year prospective study of the health of children in different ethnic groups, with particular reference to the effect of inbreeding. Eur J Hum Genet 1993; 1:206-19.

13 The Economist. Pocket world in figures. London: Profile Books Ltd; $201 \mathrm{I}$.

I4 Farndon P, Madeley M, Harvey E. Taking and drawing a family history. National Genetics Education and Development Centre, Birmingham; 2008. Available at: http://www.geneticseducation.nhs.uk

I5 Qureshi N, Gilbert P, Raeburn JA. Consanguinity and genetic morbidity in a British primary care setting: a pilot study with trained link workers. Ann Hum Biol 2003; 30: I40-47. 